\title{
EFFECT OF TRISODUM PHOSPHAT CONCENTRATION ON THE CORROSION RESISTANCE OF MAGNESIUM ALLOY AZ31B USING PLASMA ELECTROL YTIC OXIDATION (PEO)
}

\author{
AMILATIN ROHMAH \\ Department of Materials and Metallurgical Engineering, \\ Institut Teknologi Sepuluh Nopember, \\ Jalan Teknik Kimia, Keputih, 60111, Surabaya, East Java, Indonesia \\ amil.atin13@gmail.com \\ AGUNG PURNIAWAN \\ Department of Materials and Metallurgical Engineering, \\ Institut Teknologi Sepuluh Nopember, \\ Jalan Teknik Kimia, Keputih, 60111, Surabaya, East Java, Indonesia \\ agung.pur@mat-eng.its.ac.id \\ DIAH SUSANTI \\ Department of Materials and Metallurgical Engineering, \\ Institut Teknologi Sepuluh Nopember, \\ Jalan Teknik Kimia, Keputih, 60111, Surabaya, East Java, Indonesia \\ santiche@mat-eng.its.ac.id \\ * Corresponding author
}

Received 4 March 2021; Published 28 May 2021

\begin{abstract}
Magnesium is one of the candidate materials for biodegradable implants. Magnesium has the same mechanical properties as human bone, but the degradation rate of magnesium fast. The surface treatment is required to decrease the degradation rate on magnesium substrate. Plasma Electrolytic Oxidation (PEO) one of the surface treatments for magnesium/magnesium alloy. $\mathrm{PEO}$ process used an alkaline electrolyte, this research using $\mathrm{KOH}$ and $\mathrm{Na}_{3} \mathrm{PO}_{4} \cdot 12 \mathrm{H}_{2} \mathrm{O}$. The $\mathrm{KOH}$ concentration is $1 \mathrm{~g} / \mathrm{l}$ and $\mathrm{Na}_{3} \mathrm{PO}_{4} \cdot 12 \mathrm{H}_{2} \mathrm{O}$ concentration was varied $0.5 \mathrm{~g} / \mathrm{l}, 1 \mathrm{~g} / \mathrm{l}$, and $2.26 \mathrm{~g} / \mathrm{l}$. The XRD analysis results the $\mathrm{MgO}$ and $\mathrm{Mg}_{3}\left(\mathrm{PO}_{4}\right)_{2}$ and the SEM showed micropores on the surface coating. When the $\mathrm{Na}_{3} \mathrm{PO}_{4} \cdot 12 \mathrm{H}_{2} \mathrm{O}$ concentration is increased until $2.26 \mathrm{~g} / \mathrm{l}$ the pores are homogenous, dense, and large. The potentiodynamic polarization test results that PEO coating can decrease the corrosion rate of magnesium AZ31B from 50.219 mmpy to 0.1368 mmpy.
\end{abstract}

Keywords: Magnesium AZ31B, Trisodium phosphate, Plasma Electrolytic Oxidation (PEO).

\section{Introduction}

Magnesium is a light metal that has a density of about $1.74 \mathrm{~g} / \mathrm{cm}^{3}$. The density of magnesium is less than bone which is from 1.8 to $2.1 \mathrm{~g} / \mathrm{cm}^{3}$. The elasticity modulus of pure magnesium is $45 \mathrm{GPa}$ and for bones between 40 and $45 \mathrm{GPa}$. Because the elasticity modulus is similar, the magnesium is used for hard tissue engineering applications where it reduces stress shielding thereby preventing absorption by bone.

Magnesium is one of the essential minerals the body needs. In a human body weighing $70 \mathrm{~kg}$, there is approximately $30 \mathrm{~g}$ of magnesium(Song et al., 2009). Magnesium is required to maintain normal body activities with a daily supply of $420 \mathrm{mg}$. More than 300 biological processes that occur in the body require magnesium.

Magnesium is an alloying element of various types of non-ferrous metals. Because it is not strong enough in its pure form, magnesium is alloying with various unsure to obtain the special properties. Magnesium-aluminum alloys have been used as biomaterials, including AZ91 (Mg-9Al-1Zn) and AZ31 (Mg-3Al-1Zn) which contain 
Zn as an additional element (Sofyan \& Ariati, 2016). This alloy can initiate bone growth, but this alloy corrodes very quickly, so that it does not give new tissue opportunities to grow as bone substitutes. Therefore, making biodegradable materials necessary to carry out surface engineering to inhibit the degradation rate.

Surface engineering is the activity of engineering the surface of a material so that surface properties can be improved according to the application. Plasma electrolytic oxidation (PEO) is a process used for surface protection of magnesium and magnesium alloys. The PEO process is often called the Micro-Arc Oxidation (MAO) process. In this process, the metal sample is immersed in an electrolyte solution and uses a high electric voltage. By using a high electric voltage will cause light and sparks on the specimen. With high voltage, it will cause a splash on the substrate surface. The higher the voltage that loads the spark color initially white to light orange, this stage is called the micro-arc stage. As the layer thickness increases, the voltage value also increases while the number of spark decreases but the intensity increases. This makes the surface morphology rough. The increase in voltage and time is very marginal, the spark size grows larger and has a longer time than in the initial stage. The final layer formed consists of $\mathrm{MgO}$ and other phases such as magnesium silicate, magnesium phosphate, and magnesium fluoride, and others depending on the composition of the electrolyte used (Ghasemi et al., 2010).

In this research work, magnesium alloy AZ31B as a substrate and using Plasma Electrolytic Oxidation (PEO) with electrolyte $\mathrm{KOH}$ and $\mathrm{Na}_{3} \mathrm{PO}_{4} .12 \mathrm{H}_{2} \mathrm{O}$ were used.

\section{Experimental Data}

\subsection{Materials}

Magnesium alloy AZ31B with 25mm x 10mm x $5 \mathrm{~mm}$ as substrat and the specimens were ground with $\mathrm{SiC}$ papers grits of 800,1000 , and 1200 . The specimens cleaned using an ultrasonic cleaner with acetone for 10 minutes to avoid any surface contamination.

\subsection{Synthesis of Plasma Electrolytic Oxidation (PEO)}

Plasma Electrolytic Oxidation(PEO) process using alkaline electrolyte $\mathrm{KOH}$ and $\mathrm{Na}_{3} \mathrm{PO}_{4}$. The electrolyte solution for PEO was prepared with magnetic stirrer by adding $1 \mathrm{~g} / \mathrm{l} \mathrm{KOH}$ and $\mathrm{Na}_{3} \mathrm{PO}_{4}$ with variation 0,5 g/l, $1 \mathrm{~g} / \mathrm{l}$ and 2,26 g/l in distilled water. In the PEO process scheme, the sample or magnesium alloy is the anode, and the cathode is a chamber made of stainless steel.

\subsection{Characterization}

The coating phase composition was identified by XRD technique. The surface morphologies of PEO coatings were observed using scanning electron microscope (SEM) with energy disperse X-ray (EDX) detector for the chemical composition identification.

The corrosion resistance of PEO coating was evaluation with potentiodynamic polarization test. The specimens as the working electrode, counter electrode using graphite and a saturated calomel electrode as reference electrode. The test using simulated body fluid (SBF) with chemical composition introduced in Table 1.

Table 1. Reagent for SBF solution(Tadashi \& Takadama, 2006)

\begin{tabular}{|c|c|c|}
\hline No & Reagen & Jumlah \\
\hline 1 & $\mathrm{NaCl}$ & 8.03 gram \\
\hline 2 & $\mathrm{Na}_{3} \mathrm{HCO}{ }_{3}$ & 0.35 gram \\
\hline 3 & $\mathrm{KCl}$ & 0.22 gram \\
\hline 4 & $\mathrm{~K}_{2} \mathrm{HPO}_{4} \cdot 3 \mathrm{H}_{2} \mathrm{O}$ & 0.23 gram \\
\hline 5 & $\mathrm{MgCl}_{2} \cdot 6 \mathrm{H}_{2} \mathrm{O}$ & 0.31 gram \\
\hline 6 & $\mathrm{CaCl}_{2}$ & 0.29 gram \\
\hline 7 & $\mathrm{Na}_{2} \mathrm{SO}_{4}$ & 0.07 gram \\
\hline 8 & $\mathrm{HCL}$ & $1 \mathrm{M}(40 \mathrm{ml})$ \\
\hline 9 & Tris & 6.68 gram \\
\hline
\end{tabular}




\section{Results and Discussion}

\subsection{Morphology}

XRD analysis used to identify the ceramic coating on the surface coating. Fig. 1 shows the XRD result after Plasma Electrolytic Oxidation (PEO). The XRD analysis using highscore software, it can be seen that the diffraction pattern formed is similar to $\mathrm{MgO}$ at $2 \mathrm{e}$ 43.059 ${ }^{\circ}$ with ICDD 01-075-1525 while for $\mathrm{Mg}_{3}\left(\mathrm{PO}_{4}\right)_{2}$ occurs at $2 \Theta 32.7^{\circ}, 33.6^{\circ}$ with ICDD 01-088- 0413. The $\mathrm{Mg}_{3}\left(\mathrm{PO}_{4}\right)_{2}$ compound in the coating occurs due to a reaction between the anions of the phosphate salt dissolved in the cation of the Magnesium substrate. While the MgO phase is produced from the Mg substrate that is melted and oxidation.

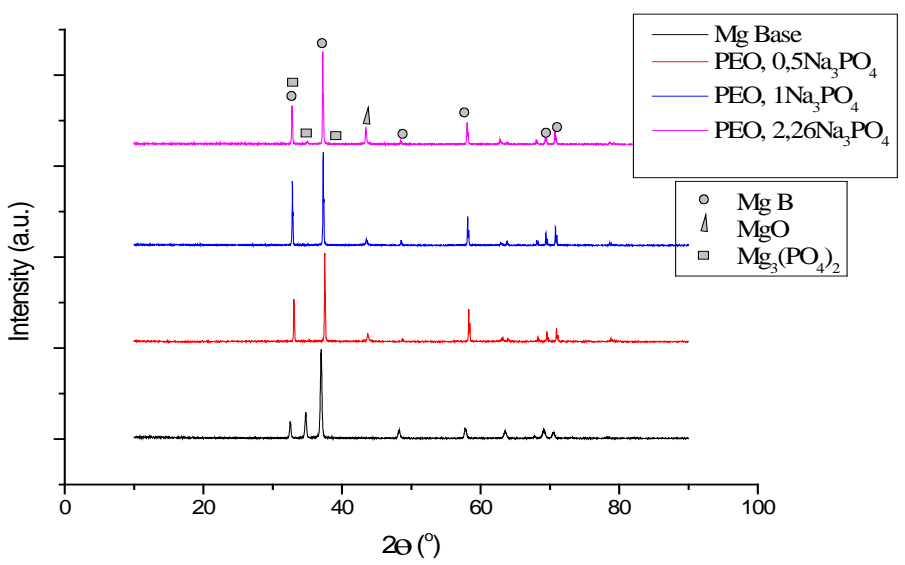

Fig. 1. X-Ray Diffraction

SEM/EDX used to analyze the surface morphology of the AZ31B magnesium alloy. Fig. 2 Shows the surface morphology using SEM, it can be seen that the surface morphology after PEO coating is porous. Pore formation this micro-sized because there are gas bubbles coming out and the oxides that are melted through the micro arc channels and are trapped during the growth of the thin films. The number and size of pores depends on the final stress during the process, higher stresses cause larger sparks and larger pores on the surface.

When 2.26g/l $\mathrm{Na}_{3} \mathrm{PO}_{4}$ was added to the electrolyte solution, it was seen that the micro pores formed were getting bigger on the surface. This is because when the resulting PEO spark process is larger with the same stress. The addition of $\mathrm{Na}_{3} \mathrm{PO}_{4}$ concentration accelerates the reaction rate so that more energy is needed to remove the looking oxide and then the number of micro arcs decreases while the size and intensity increases. The bigger of spark causes the pore bigger, but the distribution of the micropores more even. This result almost the same as the research conducted by Ma et al.(2015) where the greater contentration of $\left(\mathrm{NaPO}_{3}\right)_{6}$ added to the electrolyte, the distribution of the micropores is more even and bigger.

Fig.3. show the EDX analysis for uncoated and coating magnesium alloys AZ31B. From EDX test, it can be seen that AZ31B magnesium substrate contains P elements with a small percentage of $0.37 \%$ wt. At the time of the $\mathrm{PEO}$ process with the addition of $\mathrm{Na}_{3} \mathrm{PO}_{4}$ concentration added to the electrolyte solution, it can be seen that the percentage of $\mathrm{Mg}$ decreases while the $\mathrm{P}$ element increases. 
Rohmah et. al.
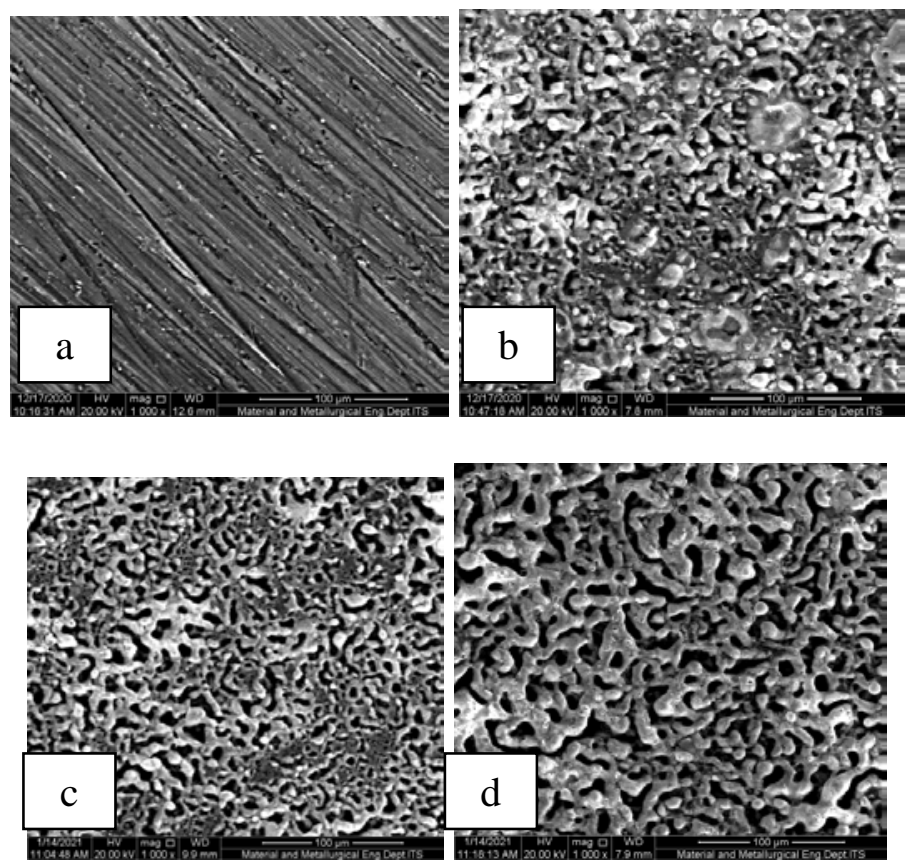

Fig. 2. SEM wit magnificent $1000 \mathrm{x}$ (a) Substrate magnesium AZ31B (b) 0,5 $\mathrm{g} / \mathrm{l} \mathrm{Na} \mathrm{PO}_{4}$ (c) $1 \mathrm{~g} / \mathrm{l} \mathrm{Na} \mathrm{PO}_{4}$ (d)2,26 g/l Na $3 \mathrm{PO}_{4}$
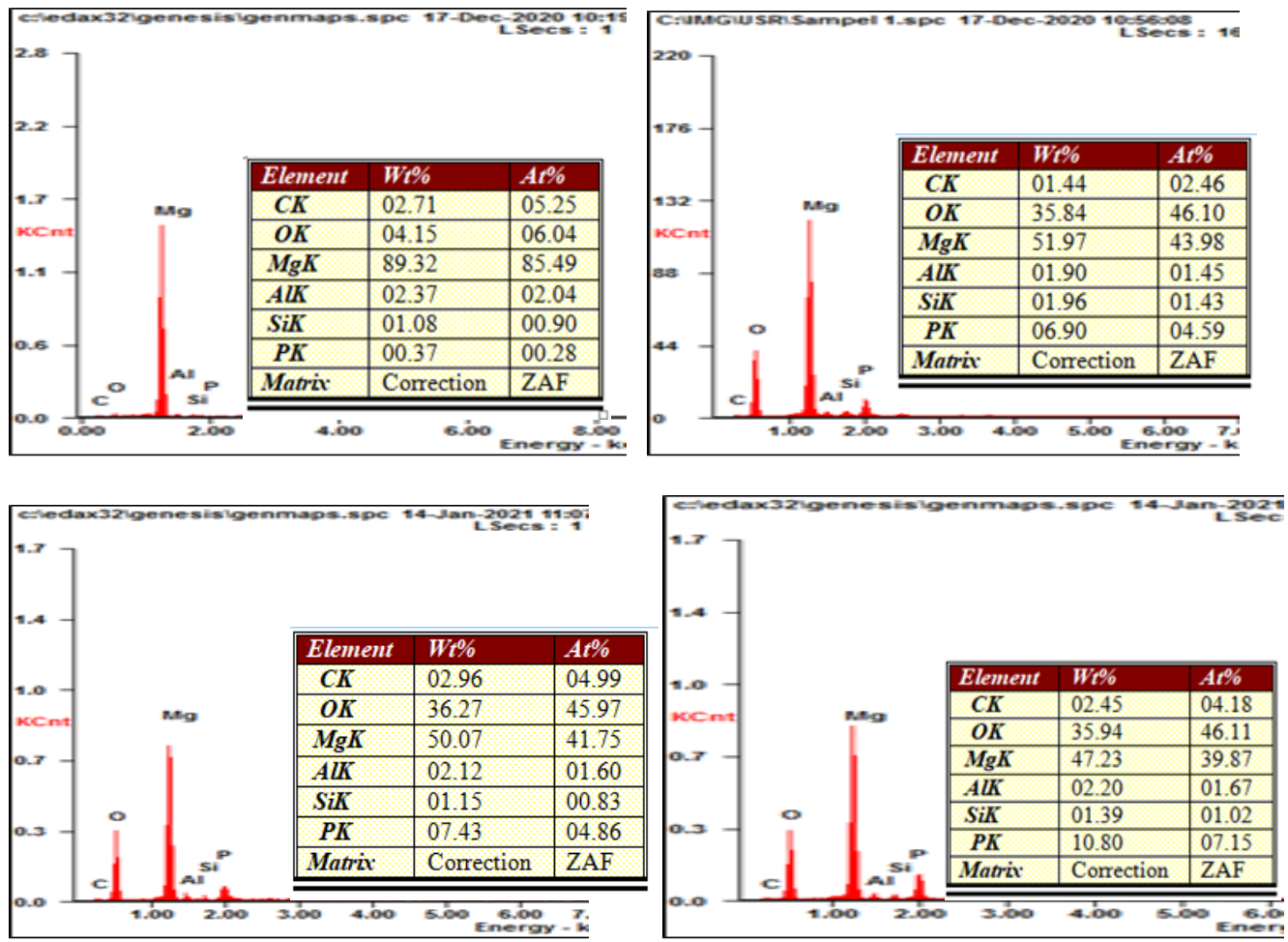

Fig. 3. EDX Analyze (a) Substrate magnesium AZ31B (b) 0,5 g/l Na $\mathrm{PO}_{4}$ (c) 1 g/l Na $\mathrm{PO}_{4}$

(d)2,26 g/l Na $3 \mathrm{PO}_{4}$ 


\subsection{Corrosion Resistant}

To determine corrosion resistance evaluated by potentiodynamic polarization technique. The corrosion behavior of magnesium specimens with and without PEO coating. The potential at which the anodic current density equals to the cathodic current density is taken as Ecorr, while different method are taken to drive the Icorr depending on the potentiodynamic polarization behavior. Fig. 4 show the polarization curve for coated and uncoated magnesium alloys AZA31B. From the potentiodyamic polarization, Ecorr was obtained before and after the PEO coating was getting up and the Icorr was getting to the left, this indicates that it is getting negative so that the corrosion resistance is getting better. From Ecorr and Icorr then an interpolation line was drawn to determine the rate of corrosion.

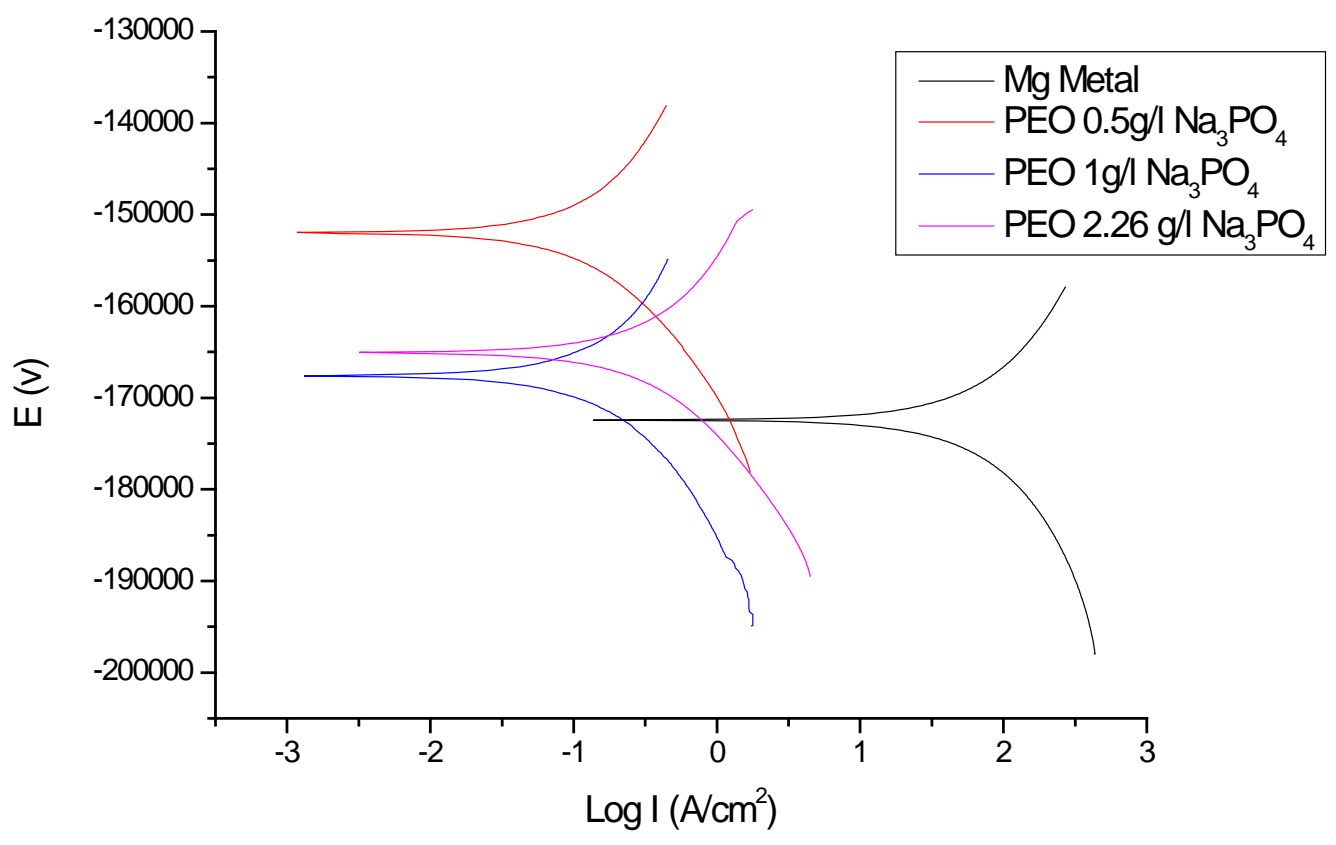

Fig. 4. Polarization Curve

From Table 2 it is found that the corrosion resistance of the magnesium alloy is 50.219 mmpy this indicates that AZ31B magnesium alloy is corroded very quickly compared to those coated with plasma electrolytic oxidation. The PEO with $\mathrm{Na}_{3} \mathrm{PO}_{4}$ electrolyte can decrease the corrosion resistance of magnesium AZ31B, the corrosion rate is $0.1368 \mathrm{mmpy}$ for $0.5 \mathrm{~g} / \mathrm{l} \mathrm{Na}_{3} \mathrm{PO}_{4}$.

Table 2. Corrosion resistance from the potentiodynamic polarization

\begin{tabular}{lccc}
\hline \multicolumn{1}{c}{ Variable } & Ecorr (v) & $\begin{array}{c}\text { Icorr } \\
(\text { Amps/cm²) }\end{array}$ & CR(mmpy) \\
\hline Mg AZ31B (no coating) & -1.7142 & $2.2 \times 10^{-3}$ & 50.219 \\
PEO 0,5g/l Na$P_{4}$ & -1.6507 & $5.9 \times 10^{-6}$ & 0.1368 \\
PEO 1 g/l Na$P_{4}$ & $-1,676$ & $7.5 \times 10^{-6}$ & 0.1723 \\
PEO 2,26 g/l Na${ }_{3} P_{4}$ & -1.524 & $1.7 \times 10^{-5}$ & 0.2445 \\
\hline
\end{tabular}

Poor corrosion performance of magnesium alloys is a main limiting factor in the application of magnesium alloys in industrial and biomedical sectors. Plasma Electrolytic Oxidation (PEO) is an effective method to overcome the problem (Barati Darband et a., 2017). PEO with ceramic coating can decrease the corrosion rate of 
Rohmah et. al.

magnesium alloys AZ31B in SBF solution. So the magnesium alloys AZ31B with ceramic coating can application to biomedical sectors.

\section{Conclusions}

PEO coating with trisodium phosphate electrolyte succeeded in forming of $\mathrm{MgO}$ and $\mathrm{Mg}_{3}(\mathrm{PO} 4)_{2}$ layers on the magnesium alloy AZ31B with porous surface. The passive film formed in electrolyte containing $0,5 \mathrm{~g} / \mathrm{l} \mathrm{Na}_{3} \mathrm{PO}_{4}$ is more protective than $10 \mathrm{~g} / \mathrm{l} \mathrm{Na} \mathrm{PO}_{4}$. The PEO coating with $\mathrm{Na}_{3} \mathrm{PO}_{4}$ electrolyte succeeded decrease corrosion resistance of magnesium alloy AZ31B form 50.219 mmpy to 0.136 mmpy.

\section{Acknowledgments}

The author would like to thank all supports for this research from ITS Surabaya.

\section{References}

Barati Darband, G., Aliofkhazraei, M., Hamghalam, P., \& Valizade, N. (2017). Plasma electrolytic oxidation of magnesium and its alloys: Mechanism, properties and applications. Journal of Magnesium and Alloys, 5(1), 74-132. https://doi.org/10.1016/j.jma.2017.02.004

Ghasemi, A., Scharnagl, N., Blawert, C., Dietzel, W., \& Kainer, K. U. (2010). Influence of electrolyte constituents on corrosion behaviour of PEO coatings on magnesium alloys. Surface Engineering, 26(5), 321-326. https://doi.org/10.1179/026708408X344671

Ma, H., Li, D., Liu, C., Huang, Z., He, D., Yan, Q., ... Shen, D. (2015). An investigation of (NaPO3)6 effects and mechanisms during micro-arc oxidation of AZ31 magnesium alloy. Surface and Coatings Technology, 266, 151-159. https://doi.org/10.1016/j.surfcoat.2015.02.033

Sofyan, B., \& Ariati, M. (2016). Magnesium dan Paduannya Sebagai Biomaterial: Sebuah Kajian Literatur Please refer this paper as: Bondan T. Sofyan, Oknovia Susanti, Myrna A. Mochtar, Magnesium dan Paduannya Sebagai Biomaterial: Sebuah Kajian Literatur, Prosiding Seminar Material. (December). Retrieved from www.researchgate.net

Song, Y., Shan, D., Chen, R., Zhang, F., \& Han, E. H. (2009). Biodegradable behaviors of AZ31 magnesium alloy in simulated body fluid. Materials Science and Engineering C, 29(3), 1039-1045. https://doi.org/10.1016/j.msec.2008.08.026

Tadashi, K., \& Takadama, H. (2006). How useful is SBF in predicting in vivo bone bioactivity? Biomaterials 27 (2006) 2907-2915, 27, 2907-2915. https://doi.org/10.1016/j.biomaterials.2006.01.017 